


\title{
Criminal Prosecution of Persons Who Have Committed Crimes in The Banking Sector
}

\section{DOI: https://doi.org/10.46398/cuestpol.3969.25}

\author{
Viktor Victorovich Pushkarev * \\ Lyudmila Nikolaevna Poselskaya ** \\ Anna Vladilenovna Skachko *** \\ Anatoly Vyacheslavovich Tarasov **** \\ Leyla Sasikbekovna Mutalieva ****
}

\begin{abstract}
The objective of the article was to analyze the process of criminal prosecution of people accused of committing crimes against the banking sector in the Russian Federation. Detecting such crimes, identifying the people who committed them in and compensating for the damages caused by such acts is the most difficult task for law enforcement officials in Russia. The most important part of these activities are procedural questions about the timing of the commencement of criminal proceedings and the procedure for their implementation in pre-trial proceedings. The methodological basis of this research is formed by the processing of the results of criminal cases, the results of surveys of researchers and detectives, members of the educational and methodological group of the Ministry of Internal Affairs of the Russian Federation. The authors have proposed the drafting of article 5, paragraph 55, of the Code of Criminal Procedure of the Russian Federation and its corresponding amendments to article 11. It is concluded that these contributions will make it possible to carry out the procedural work on compensation for damages caused by a crime in a much more effective manner.
\end{abstract}

Keywords: bank offences; criminal prosecution; pre-trial proceedings; termination of criminal proceedings; Russian Federation.

* Plekhanov Russian University of Economics, Moscow, Russia. ORCID ID: https://orcid.org/ooooooo2-3536-6497. Email: pushkarev.v.v@bk.ru

* Moscow University of the Ministry of Internal Affairs of Russia named by V.Ya. Kikot, Moscow, Russia. ORCID ID: https://orcid.org/oooo-0o02-9213-5388. Email: poselskaya.l.n@bk.ru

*** Doctor of law, Professor of the Department of Criminal Procedure Law of the North Caucasus branch of the Russian Academy of Justice, Krasnodar, Russia. ORCID ID: https://orcid.org/oooo-0002-28788413. Email: skachko.a.v@yandex.ru

**** Candidate of Legal Sciences, Honoured Lawyer of Kuban, Associate Professor at the Department of Criminal Procedure Law, North-Caucasus branch of Russian University of Justice, Krasnodar, Russia. ORCID ID: https://orcid.org/oooo-0002-0564-6447. Email: anatoly.tarasov@inbox.ru

***** St. Petersburg University of State Fire Service of Ministry of Emergency Situations of Russia, St. Petersburg, Russia. ORCID ID: https://orcid.org/oooo-0002-4847-9140. Email: mutalieva.l.s@mail.ru 
Viktor Victorovich Pushkarev, Lyudmila Nikolaevna Poselskaya, Anna Vladilenovna Skachko, Anatoly Vyacheslavovich Tarasov y Leyla Sasikbekovna Mutalieva

396

Criminal Prosecution of Persons Who Have Committed Crimes in The Banking Sector

\section{Enjuiciamiento penal de personas que han cometido delitos en el sector bancario}

\section{Resumen}

El objetivo del artículo fue analizar el proceso de enjuiciamiento penal de personas sindicadas de cometer de delitos contra el sector bancario en la federación rusa. La detección de tales delitos, la identificación de las personas que los cometen y la compensación por los daños causados, por tales actos, es la tarea más difícil para los agentes del orden en Rusia. La parte más importante de estas actividades son las cuestiones procesales sobre el momento en que comienza el proceso penal y el procedimiento para su implementación en las diligencias previas al juicio. La base metodológica de esta investigación está formada por el procesamiento de los resultados de las causas penales; los resultados de encuestas a investigadores y detectives, miembros del grupo educativo y metodológico del Ministerio del Interior de la Federación de Rusia. Los autores han propuesto la redacción del párrafo 55 del artículo 5 del Código de Procedimiento Penal de la Federación de Rusia y sus correspondientes enmiendas al artículo 11. Se concluye que estos aportes permiten llevar a cabo la labor procesal sobre la indemnización por daños causados por un delito de manera mucho más eficaz.

Palabras clave: delitos bancarios; enjuiciamiento penal; procedimientos previos al juicio; terminación del proceso penal; federación rusa.

\section{Introduction}

The necessity of criminal prosecution or refusal from it are predetermined by the purpose of criminal proceedings. Without including criminal prosecution in the purpose of criminal proceedings, the latter loses its significance, social value and efficiency in the legal and law enforcement sense. That is why achieving the purpose of criminal proceedings is possible only when criminal prosecution is carried out or when it is refused. Thus, criminal prosecution is a semantic concept for determining the purpose of criminal proceedings, solving the tasks arising from it, contributing to its achievement. 


\section{Materials and methods}

The empirical basis consists of the results of 47 criminal cases; questionnaire results among 25 investigators and detectives, 60 members of the teaching group of the Ministry of Internal Affairs of the Russian Federation, Moscow University of the Ministry of Internal Affairs. Based on the study of the law enforcement practice of investigators of territorial internal affairs bodies investigating crimes in the sphere of banking, expressed in the materials of specific criminal cases; obtained and processed data from a sociological study on the state of practice in investigating crimes in the banking sector; corrective data from the Investigative Department of the Ministry of internal Affairs of Russia was received and studied. The analytical research method has enabled us to draw several essential conclusions that resolve the question which serves as the hypothesis for this study.

\section{Results analysis}

The interpretation of the notion "criminal prosecution" allows to define it as accusatory procedural activity of the competent officers and authorities, directed against a specific person, which can be confirmed by issuing the procedural decision on initiation of criminal case, the conduct in respect of his investigative and legal proceedings as proof of his involvement in the crime by establishing the circumstances referred to in article 73 of the Criminal Procedure Code (Criminal Procedure Code of the Russian Federation No. 174-FZ, 2001b) of the Russian Federation, other measures undertaken for the purposes of proof or evidence that there is a suspicion against him (in particular, explanation in accordance with part 1 of article 51 of the Constitution of the Russian Federation the right not to testify against oneself) (Constitutional Court of the Russian Federation, 2000).

This approach demonstrates a broad view 5 of the Criminal Procedure Code (Criminal Procedure Code of the Russian Federation No. 174-FZ, 2001d) of the Russian Federation, when to determine the initial moment of criminal prosecution, the actual position of the person against whom the criminal prosecution is being carried out must be taken into account.

Defining the specific moment of the beginning of criminal prosecution, the respondents of the conducted sociological survey ( $84 \%$ of investigators) also indicated that it can begin at the stage of initiation of criminal proceedings in the course of investigative and procedural actions in accordance with article 144 of the Criminal Procedure Code of the Russian Federation (Criminal Procedure Code of the Russian Federation No. 174FZ, 2001a), which affects the rights and freedoms of a person in respect of whom a report of a crime is being verified. 
Viktor Victorovich Pushkarev, Lyudmila Nikolaevna Poselskaya, Anna Vladilenovna Skachko, Anatoly Vyacheslavovich Tarasov y Leyla Sasikbekovna Mutalieva

Stated arguments lead to the reasonable conclusion that the beginning of criminal prosecution needs to find its normative expression in paragraph 55 of article 5 of the Code of Criminal Procedure, which is proposed to be amended as follows: "55) criminal prosecution the indictment procedural activity carried out by the prosecution in order to expose a specific person of committing a crime, seriously and directly affecting his position."

The adoption of this regulatory innovation will solve a number of significant tasks of criminal proceedings, which will be considered on the example of crimes committed in the credit and banking sector, the first of which is compensation for criminally caused harm, otherwise this task becomes potentially unattainable.

So, for example, unidentified persons from among the heads of $\mathrm{CB}$ "Universaltrast “(JSC) committed theft of the Bank's funds by lending to one-day firms, causing damage in the amount of 122 million rubles, but the property subject to arrest was not identified and the damage was not compensated.

Koval Yu. N., being the chairman of the board of the bank CB "SOTSECONOMBANK" (LLC) and Rombakh O. V., in the period from 23.03.2010 to 26.10.2010, acting in collusion with Rombakh O. V., committed theft of the Bank's property in a particularly large amount. The damage equal to 1.3 billion rubles has not been reimbursed, and the property subject to seizure has not been established.

The accused Monkhey M. I. and Kazakova N. V. stole funds of JSC "Miraf-Bank " in the amount of 100 million rubles under the guise of issuing a loan to LLC "Grizar", the damage was not compensated, the property was not established.

In another criminal case on the commission of a crime by Timonium A. V. jointly with the Zavertyaev M. I. of misappropriation of funds belonging to JSC "PV-Bank", represented by GK "ASV" in the amount of 120 million rubles, initiated in 2012, the petition for seizure of property was prepared only in 2019 and 24.05.2019 the case was directed to the Meshchansky district court.

The examples listed above and other indicate the symptoms of imperfect criminal procedure legislation and practice of its application in the investigation of economic crimes, which concern mostly the issues of the beginning and implementation of criminal prosecution of persons who have committed them.

The most common reason for initiating a criminal case is a statement of a crime received from a credit and financial institution. The application can also be submitted from the Central Bank of the Russian Federation (Bank of Russia) or the State Corporation "Deposit Insurance Agency" 
(hereinafter referred to as the "DIA" group). Another reason for conducting an inspection may also be a report on the discovery of signs of a crime, but it is necessary to take into account the provisions of part 3 article 20 of the Criminal Procedure Code of the Russian Federation.

Verification of a crime report is carried out using a set of investigative and other procedural actions specified in part 1 of article 144 of the Criminal Procedure Code of the Russian Federation (Criminal Code of the Russian Federation No. 174-FZ, 2001a), as well as with the conduct by the body of inquiry of operational-search measures on behalf of the investigator.

At the stage of criminal proceedings initiation, not all circumstances are subject to determination, but only those data that are of key importance in the commission of a crime. At the same time, the investigator needs to conduct certain procedural and investigative actions in order to collect enough factual data, which in the future, when initiating a criminal case, can become evidence and be attached to the materials a criminal case.

When verifying received materials the investigators have to consider the fact that according to the statements of the Central Bank and GK "ASV" there are problems in locating the original documents and establishing the whereabouts of persons whose registration is not the same as place of residence. In order to avoid violating the terms of pre-investigation checks, it is necessary to immediately clarify these issues.

The actual data that are the basis for initiating a criminal case may be established by removing and further studying by the person performing the preliminary check, those documents submitted by the borrower to a bank or other credit institution for obtaining a credit supply, as well as bank documents accompanying the procedure for registration and obtaining credit funds.

Receiving an application from the Civil Code "DIA" does not mean that the preliminary investigation authorities unconditionally accept the received materials and the formality of the upcoming verification of the report of a crime.

For example, the investigator repeatedly made decisions to refuse initiating criminal proceedings, which were subsequently canceled and sent for additional verification. However, as a result of the audit bodies of preliminary investigation came to the conclusion, that in determining the value of shares of JSC "UK ORF" it is incorrect to use the method of net assets, as these shares were actively traded on MICEX at a cost of 6.8 RUB not just by affiliates, but also by persons not affiliated with the Bank and the beneficiary (from 10-16\% share of the total number of shares). Therefore, the applicant's conclusion that they are illiquid is premature and unfounded. Shares of JSC "UK ORF" acquired by the Bank upon the exchange of assets between the Bank's shareholders in 2013 held by the beneficiary at a price 
Viktor Victorovich Pushkarev, Lyudmila Nikolaevna Poselskaya, Anna Vladilenovna Skachko, Anatoly Vyacheslavovich Tarasov y Leyla Sasikbekovna Mutalieva

of 0,10 rubles in order to increase the value of assets, as confirmed by the requirements of the Central Bank of the Russian Federation to the Bank and were sold for a high price, which confirms the testimony of a number of check individuals on the pursuit of their goal of making profit from deals of these securities and increase the amount of cash in circulation the Bank. Thus, the investigator decided to refuse to initiate criminal proceedings against specific individuals under part 4 of article 16o, part 2 of article 201 of the Criminal Code, on the grounds established by clause 2 part 1 article 24 of the Criminal Code of the Russian Federation, that is, because of absence in their actions of the above mentioned crimes.

Decisions to initiate criminal proceedings for crimes in the credit and financial sphere are taken if there is sufficient data indicating the signs of a crime, and if there are signs indicated in the order of the Deputy Minister-head of the Investigative Department Internal Affairs No. 55 of the Russian Federation dated October 26, 2011 "On the organization of departmental control when reviewing audit materials in accordance with article 144-145 of the Criminal Code of the Russian Federation (Criminal Procedure Code of the Russian Federation No. 174-FZ, 2001a) on economic crimes and corruption" and of the Ministry of Internal Affairs Order of 1 December 2016 No. 785 "On the organization of communications on certain types of economic crimes", only after consultation with the head of the preliminary investigation bodies territorial bodies of the MIA of Russia.

When checking reports of encroachments on bank credit facilities, the investigator closely interacts with the employees of the inquiry body who accompany the material. The circle of persons with information relevant to the case is determined and worked out, as well as the circle of persons involved in the commission of the crime.

In accordance with paragraph 4 of part 2 of article 38 of the Criminal Code the investigator submits written assignments to operational staff on the conduct of investigative activities aimed at locating stolen property, verification of information about the movement of stolen funds in bank accounts; and other events, depending on the circumstances of the theft.

The staff of the investigative units inquiring criminal cases of this category, focus should be oriented towards validation at the initial stage of investigation into signs of crimes specified in articles 172.1, 173.1, 173.2, 174, 174.1, 187, 193.1, 210 of the Criminal Code of the Russian Federation (henceforth, The Criminal Code), and if identified, the decision-making of additional qualification according to the articles.

For example, 18.01.2019 the senior investigator for ATS SU AMIA Russia's Orenburg region during the pre-investigation (KUSP No. 3308 from 15.06.2018) against the directors of the JSK "BSL" was detected the fact of committing a crime under article 172.1 of the Criminal Code of Russian Federation, as the leaders of JSK "BSL", making transactions with securities affiliates, overstated the financial result on transactions with 
securities and provided false information in statements for the Central Bank of the Russian Federation, in order to conceal stipulated by the legislation of the Russian Federation grounds for mandatory revocation of license organization and destination organization of the interim administration.

To establish the property status of the defendants, pre-screening, the availability of real estate, vehicles, cash in their accounts, the availability of shares in the authorized capital of legal entities, establishment of affiliated organizations and individuals, involved in the commission of crimes in credit-financial sphere, identify the possible legalization of proceeds of crime, employees of internal affairs bodies according to the materials of checks and criminal cases sent relevant inquiries to the state bodies, financial organizations, banks, Interregional Directorate of the Federal Service for financial monitoring (Rosfinmonitoring).

At the same time, the investigator should take into account the specifics of interaction with the FSFM, accounting for which can have a positive impact on detecting the legalization of criminal income.

The FSFM sends materials about suspicious transactions to law enforcement agencies not promptly enough.

Financial intelligence materials are of an orientation nature and require additional verification, which is why they are used for planning operational and investigative activities and further procedural actions. A problem that arises in the course of interaction of Internal Affairs Investigators with Rosfinmonitoring units is the presence of a security label on the received information, which is why it cannot be included in the criminal case file, and additional requests must be sent to the relevant authorities and institutions.

In the vast majority of cases, Rosfinmonitoring information is not used in criminal investigations, due to the length of execution of requests for financial audits and the related lack of relevance of information at the time of receipt of the results, since this information has already been independently obtained by investigators from registration authorities and credit organizations during the preliminary investigation, by sending appropriate requests (in some cases, the criminal case has already been sent to the court).

Information gathering is also performed using the information systems of subjects of the financial-economic activities, databases of the MIA, as well as confidential personnel and the capabilities of the Search and Rescue Units and the Bureau of Special Technical Activities of the MIA.

In pursuance of the investigator's order, instructions are sent to the territorial MIA, the Office of Economic Security and Anti-Corruption, and CID of the relevant subjects of the Russian Federation for conducting operational search measures to establish the location of stolen property, 
Viktor Victorovich Pushkarev, Lyudmila Nikolaevna Poselskaya, Anna Vladilenovna Skachko, Anatoly Vyacheslavovich Tarasov y Leyla Sasikbekovna Mutalieva

objects of investment of stolen funds, and the circumstances of the criminal origin of funds, real estate and other material values are established.

The property status of relatives of the person who committed the crime, acquired during his criminal activity, must also be established. An important role at this stage of the work of investigators is provided by interaction with operational units, which is carried out by obtaining information about the connections of suspects, their relatives; the frequency of their trips abroad, as well as movement within the country, the purpose of travel; their income obtained legally, which is compared with expenses and the availability of property, is established. In case of non-compliance, additional verification measures are organized.

When conducting interviews and interrogations of relatives and friends of a suspected person, among other issues, objects of property owned are established. Investigators send inquiries to various organizations (traffic police, GIMS, the Rostekhnadzor, the Federal service for state registration, BTI, the Federal service for state registration, cadastre and cartography, FNS (participation in legal entities), pension Fund, credit institution, etc.) with the aim of establishing the presence of suspects (accused) movable and immovable property, availability of funds in the accounts, deposits or deposited in banks and other credit organizations.

When establishing the facts of legalization (laundering) of property obtained by criminal means, the investigator should take into account the fact that the direction of funds of an illegally obtained loan to ensure the normal financial and economic activities of the enterprise, expressed, for example, in the purchase of materials and fixed assets, payment for services of suppliers, etc., is mistakenly recognized as legalization (laundering) and leads to a verdict of acquittal in terms of unlawfully imputed.

Special attention should be paid to the measures taken by the body of inquiry aimed at compensating for the damage caused by the crime. Shortcomings lead to significant omissions in this work (Ivanov et al., 2020: Ivanov and Kruglikov, 2020).

So, the help on criminal cases about the crimes in credit-financial sphere in 2019 at Department of the Ministry of Internal Affairs of Russia across the Sakhalin region (2020) shows that the damage on the ended criminal cases has made 4860585 rubles, voluntarily refunded in the amount of 969704 rubles, or $19,95 \%$, the lien on the property in order to recover damages did not overlap.

Joint discussions of inspection materials with operational divisions are necessary prior to their registration, in order to collect complete and high-quality materials. All verification materials, and subsequently for each criminal case, should be subject to security measures aimed at compensating damages, identifying assets that can be seized, as well as property obtained 
by criminal means. If necessary, actions should be taken to identify, seize and return from abroad assets obtained as a result of a crime commission, by sending requests for legal assistance to the competent authorities of foreign States.

The highest performance is achieved when the organization of interdepartmental interaction of law enforcement bodies on counteraction to crimes in credit-financial sphere in the form of a permanent interdepartmental group, comprised of staff from the Office of Economic Security and Anti-Corruption, prosecutors, the IRS and others, as well as representatives of the Bank of Russia and GK "ASV".

Thus, after receiving and evaluating the information, the investigator, in accordance with article 115 of the Code of Criminal Procedure (Criminal Procedure Code of the Russian Federation No. 174-FZ, 2001c), with the consent of the head of the investigative body shall immediately apply to the court a reasoned petition for seizure of property of suspects (accused) to ensure execution of civil action, recover a fine, other property collectings or possible confiscation of property, specified in part 1 of article 104.1 of the Criminal Code.

In accordance with article 115 of the Criminal Procedure Code of the Russian Federation (Criminal Procedure Code of the Russian Federation No. 174-FZ, 2001c), it is possible to impose an arrest on the property of only a suspect or accused. This leads to the fact that when performing preliminary verification of a report of a crime (up to 30 days) in relation to a particular person, it is impossible to perform actions to compensate for damage caused by this crime.

In such circumstances, it is necessary to orient investigators and heads of investigative bodies on the earliest possible granting of the status of a suspect (accused), a person who has committed a crime. This fact leads to errors of prosecution and difficulties of proof caused by artificial acceleration of pre-trial criminal proceedings.

More reasonable is the situation in which priority attention is paid to preventing the initiation of criminal cases for crimes in the credit and financial sphere upon the crime commission, if there is data on specific persons subject to criminal prosecution. However, in such cases, the issue of compensation for damages is "technically" postponed until criminal proceedings are initiated. Conditions are created for further concealment and legalization of stolen goods.

In this regard, the proposed wording of paragraph 55 of article 5 of the Criminal Procedure Code of the Russian Federation and its corresponding amendments to article 115 of the Criminal Procedure Code of the Russian Federation (Criminal Procedure Code of the Russian Federation No. 174FZ, 2001c) would allow to conduct procedural work on compensation for 
Viktor Victorovich Pushkarev, Lyudmila Nikolaevna Poselskaya, Anna Vladilenovna Skachko, Anatoly Vyacheslavovich Tarasov y Leyla Sasikbekovna Mutalieva

404

Criminal Prosecution of Persons Who Have Committed Crimes in The Banking Sector

damage caused by a crime much more effectively. Initial giving the status of the accused to an individual as described in the first situation entails a much more serious procedural consequences in case of the fallacy of hasty decision, unlike the action for the seizure of property which must take place under review of a crime report if it is against a specific person, the involvement of which to act is fairly reflected in the materials of the internal and external, including means operative-investigative activities, inspections.

\section{Conclusions}

The proposed innovation will not only correctly determine the moment when criminal prosecution of a particular person begins, but will also fully ensure their right to defense and give it a criminal procedural status, and extend the possibility of lawful and justified seizure of their property, prevent the possibility of continuing its criminal use and achieve the goal of compensating for damage caused by a crime, ensuring the achievement of the purpose of criminal proceedings.

Undoubtedly, such an innovation will require the development of a normative consolidation of the criminal procedural status of persons in respect of whom the report of a crime is verified, since they are directly mentioned in part 1 of article 144 of the Code of Criminal Procedure of the Russian Federation (Criminal Procedure Code of the Russian Federation No. 174-FZ, 2001a), however, has so far been unreasonably restricted in significant rights and legitimate interests in the sphere of criminal proceedings, the subjects of which they undoubtedly are. The need to expand the rights of participants of criminal procedure relations at the stage of verification of a crime report and the extension system of safeguards compliance confirms not only the emerging law enforcement practice, but $91 \%$ of investigators who believe that the beginning of criminal prosecution should not be possible without giving the criminal-procedural status to participants of these relations.

To improve the performance for compensation of harm caused as a result of the crime, the investigator should draw up a protocol of examination of the person in respect of whom they check the message on the receipt, the suspect or the accused with the relevant articles of the Criminal Code, according to which voluntary compensation for property damage, other actions directed on compensation of harm, caused to the victim of crime, are treated, in accordance with part 1 of article 61 of the Criminal Code (Criminal Procedure Code of the Russian Federation No. 63-FZ, 1996), as the circumstances mitigating the punishment. 


\section{Bibliographic References}

CONSTITUTIONAL COURT OF THE RUSSIAN FEDERATION. 2000. Resolution No. 11-P "Regarding the constitutionality of provisions of Art. 47 Part 1 and Art. 51 Part 2 of the Criminal Procedure Code of RSFSR with regard to the claim of V.I. Maslov". June 27. Available online. In: http:// pravo.gov.ru/proxy/ips/?docbody $=\& l i n k \_i d=3 \&$ nd $=102066471 \& b p a=$ cdooooo\&bpas $=$ cdooooo\&intelsearch $=\% \mathrm{~F} 1 \% \mathrm{~EB} \% \mathrm{E} 5 \% \mathrm{E} 4 \% \mathrm{~F} 1 \%$ F2\%E2\%E2\%E8\%E5++. Consultation date: 06/11/2020.

CRIMINAL PROCEDURE CODE OF THE RUSSIAN FEDERATION No. 174-FZ. 2001a. Article 144: Procedure for Considering a Report of a Crime. December 18. Available online. In: http://www.consultant.ru/ document/cons_doc_LAW_34481/. Consultation date: 06/11/2020.

CRIMINAL PROCEDURE CODE OF THE RUSSIAN FEDERATION No. 174-FZ. 2001b. Article 73: Circumstances to be proved. December 18. Available online. In: http://www.consultant.ru/document/cons_doc_ LAW_34481/. Consultation date: 06/11/2020.

CRIMINAL PROCEDURE CODE OF THE RUSSIAN FEDERATION No. 174FZ. 2001c. Article 115: Seizure of property. December 18. Available online. In: http://www.consultant.ru/document/cons_doc_LAW_34481/. Consultation date: 06/11/2020.

CRIMINAL PROCEDURE CODE OF THE RUSSIAN FEDERATION No. 174FZ. 2001d. Article 5: Basic concepts used in this Code. December 18. Available online. In: http://www.consultant.ru/document/cons_doc_ LAW_34481/. Consultation date: 06/11/2020.

CRIMINAL PROCEDURE CODE OF THE RUSSIAN FEDERATION No. 63FZ. 1996. Article 61: Circumstances mitigating the punishment. June 13. Available online. In: http://www.consultant.ru/document/cons_doc_ LAW_10699/. Consultation date: 06/11/2020.

DEPARTMENT OF THE MINISTRY OF INTERNAL AFFAIRS OF RUSSIA FOR THE SAKHALIN REGION. 2020. Information on the performance of the investigation divisions of the Ministry of Internal Affairs in the Sakhalin region on crimes in credit and monetary sphere. Available online. In: https://65.мвд.pф/duty/Otcheti/Otchet_nachalnika_ UMVD_Rossii_po_Sahalin/item/19733045/ . Consultation date: 06/11/2020.

IVANOV, Dmitriy Aleksandrovich; ESINA, Alla Sergeevna; FADEEV, Pavel Vladimirovich; CHASOVNIKOVA, Olga Georgievna; ZORINA, Elena Andreevna. 2020. "Crime victim compensation" In: Revista Gênero e Direito. Vol. 9, No. 4, pp. 753-759. 
Viktor Victorovich Pushkarev, Lyudmila Nikolaevna Poselskaya, Anna Vladilenovna Skachko, Anatoly Vyacheslavovich Tarasov y Leyla Sasikbekovna Mutalieva

406 Criminal Prosecution of Persons Who Have Committed Crimes in The Banking Sector

IVANOV, Dmitriy Aleksandrovich; KRUGLIKOV, M.A. 2020. "Mezhdunarodnyye standarty mer presecheniya i ikh implementatsiya v zakonodatel'stvo Rossiyskoy Federatsii" In: Vserossiyskiy kriminologicheskiy zhurnal. Vol. 14, No. 4, pp. 623-630. 
Vol. 39 N $^{\circ} 69$

Esta revista fue editada en formato digital y publicada en julio de 2021, por el Fondo Editorial Serbiluz, Universidad del Zulia. Maracaibo-Venezuela 